\title{
Localized scleroderma: assessment of the therapeutic response to phototherapy
}

\author{
Esclerodermia cutânea: avaliação da resposta terapêutica à fototerapia
}

\section{Roberta Buense ${ }^{1}$ Marcio Bouer ${ }^{3}$}

\begin{abstract}
BACKGROUND: Scleroderma is a chronic autoimmune disease characterized by progressive connective tissue sclerosis and microcirculatory changes. Localized scleroderma is considered a limited disease. However, in some cases atrophic and deforming lesions may be observed that hinder the normal development. Literature reports indicate phototherapy as a therapeutic modality with favorable response in cutaneous forms of scleroderma.

OBJECTIVES - This study had the purpose of assessing the phototherapy treatment for localized scleroderma.

METHODS - Patients with localized scleroderma were selected for phototherapy treatment. They were classified according to the type of localized scleroderma and evolutive stage of the lesions. Clinical examination and skin ultrasound were used to demonstrate the results thus obtained.
\end{abstract}

RESULTS - Some clinical improvement was observed after an average of 10 phototherapeutic sessions. All skin lesions were softer at clinical palpation with scores reduction upon pre and post treatment comparison. The ultrasound showed that most of the assessed lesions presented a decrease in dermal thickness, and only five maintained their previous measure. Treatment response was similar regardless of the type of phototherapeutic treatment employed.

Conclusions - The proposed treatment was effective for all lesions, regardless of the phototherapeutic modality employed. The improvement was observed in all treated skin lesions and confirmed by clinical evaluation and skin ultrasound.

Keywords: PUVA therapy; Phototherapy; Scleroderma, localized; Ultrasonography; Ultrasound, high-intensity focused, transrectal

Resumo: FunDAMENTOS: A esclerodermia é uma doença autoimune caracterizada pela esclerose progressiva do tecido conjuntivo e alterações da microcirculação. A forma cutânea é considerada uma doença autolimitada. No entanto, em alguns casos, ocorrem lesões atróficas, deformantes, que dificultam o desenvolvimento normal. Relatos da literatura apontam a fototerapia como uma modalidade terapêutica com resposta favorável nas formas cutâneas da esclerodermia.

Oвјетіvos: Este trabalho teve como objetivo avaliar o tratamento da esclerodermia cutânea com fototerapia.

MÉTODOs: Foram selecionados pacientes com diagnóstico de esclerodermia cutânea para o tratamento com fototerapia, os quais foram classificados de acordo com o tipo clínico e o estágio evolutivo das lesões. Utilizou-se o exame clínico e a ultrassonografia da pele como metodologia para demonstrar os resultados obtidos com o tratamento proposto.

Resultados: Foi observado o início da melhora clínica das lesões com média de 10 sessões de fototerapia. A palpação clínica mostrou amolecimento em todas as lesões estudadas, com redução nos escores de avaliação estabelecidos. No exame de ultrassom, a maioria das lesões avaliadas mostrou diminuição da espessura da derme, e apenas cinco mantiveram sua medida. Não se observou diferença na resposta ao tratamento de acordo com o tipo de fototerapia instituída.

Conclusões: O tratamento proposto foi efetivo em todas as lesões, independentemente do tipo de fototerapia realizada. A melhora foi observada em todas as lesões tratadas e comprovada pela avaliação clínica e pelo exame de ultrassom da pele.

Palavras-chave: Esclerodermia localizada; Fototerapia; Terapia PUVA; Ultrassom focalizado transretal de alta intensidade; Ultrassonografia

Received on 15.08.2010

Approved by the Advisory Board and accepted for publication on 21.01.11.

* Work performed at the Allergy and Phototherapy Sector of the Dermatology Clinic of the Irmandade da Santa Casa de Misericórdia de São Paulo, and the ultrasound exams performed at the Radiology Institute of the Hospital das Clínicas of the Faculdade de Medicina of the Universidade de São Paulo (InRad/HC - FMUSP) - São Paulo (SP), Brasil.

Conflict of interest: None / Conflito de interesse: Nenbum

Financial funding: None / Suporte financeiro: Nenbum

Master - Second assistant physician of the Irmandade da Santa Casa de Misericórdia de São Paulo - São Paulo (SP), Brasil.

$\mathrm{PhD}$ - Assistant professor of the Faculdade de Ciências Médicas of the Santa Casa de São Paulo (FCMSC-SP); Responsible for the Allergy and Phototherapy Sector of the Dermatology Clinic of the Irmandade da Santa Casa de Misericórdia de São Paulo - São Paulo (SP), Brasil.

Radiologist - Research Physician of the Ultrasound Service of the Radiology Institute of the Hospital das Clínicas of the Faculdade de Medicina of the Universidade de São Paulo (InRad - HC-FMUSP) - São Paulo (SP), Brasil. 


\section{INTRODUCTION}

Scleroderma is a chronic autoimmune disease, characterized by progressive sclerosis of the connective tissue and microcirculatory changes. ${ }^{1,2}$ The aetiology of the disease is not yet elucidated. In its pathogenesis there is damage to the vascular endothelium, with inflammatory and immunologic activation, leading to an increased synthesis of collagen and other proteins of the extracellular matrix. ${ }^{3}$

Localized scleroderma is an auto-limited disease and the superficial forms resolve in months or years, leaving few or no sequelae. ${ }^{4}$ However, in ten percent of the cases there is the development of atrophic, deforming lesions that delay or hinder the normal development. ${ }^{5}$ This dermatosis can be classified according to clinical types, as follows: morphea scleroderma, in drops, fronto-parietal "en coup de sabre" with or without facial hemi atrophy (ParryRomberg Syndrome), linear or segmentary, deep (subcutaneous), generalized and pan-sclerotic of childhood. ${ }^{1}$

The clinical aspect presents with two phases of development. At the beginning the lesions are erythematous or violaceous macules, with smooth surface and white-yellowish center, which progressively become depressed and hardened. There is a surrounding erythematous or sometimes violaceous halo, called lilac ring. At this stage, called inflammatory, the pinching of the skin at palpation is difficult. The lesion progresses with a white-ivory color on the central, atrophic area, surrounded by a sclerotic plaque. This is called the stage of stable disease. ${ }^{2,6,7}$

There is no consensus in terms of the efficacy of the therapeutic modalities used. The improvement associated with many medications might result from the normal progress of the disease. Controlled, randomized, well performed studies are rare. ${ }^{1,5}$ Reports from the literature indicate that phototherapy is a therapeutic modality with favourable response on the cutaneous forms of scleroderma. ${ }^{2,5,8,9}$ Phototherapy, due to its immunosuppressant effect, inhibits the collagen production and induces an increased synthesis of collagenase. ${ }^{10}$

The objective of this study was to assess the treatment of cutaneous scleroderma with phototherapy. The clinical examination and the ultrasound were used as the methodology to demonstrate the results achieved with the proposed treatment.

\section{MATERIAL AND METHODS}

During the year 2007, 11 patients with diagnosis of cutaneous scleroderma were selected for the treatment with phototherapy.

In terms of sex distribution, seven patients (64\%) were women and four (36\%) were men, nine
(82\%) patients were white and two (18\%) had dark skin. In terms of age, two (18\%) were on the age bracket $1-9$ years, five (46\%) on the $10-19$ years and four (36\%) on the $20-29$ years.

These patients were classified according to the type of cutaneous scleroderma and the evolutive stage of the lesions: inflammatory or stable. In total 17 lesions of scleroderma were studied, as patients number six and nine had two lesions each. From patient number eight, with linear type lesion, two distinct places were analysed. From patient number three, with the generalized form, four places were considered for analysis due to the extension of the disease.

The group had eight lesions with the cutaneous morphea form (47\%), five with the linear form (29\%) and four with the generalized form of cutaneous scleroderma $(24 \%)$. In relation to the evolutive stage, the distribution consisted of eight (48\%) lesions on the inflammatory stage and nine (52\%) on the stable stage.

The types of phototherapy chosen for this study were systemic PUVA, topical PUVA and narrow band UVB. Each patient was submitted to only one type of phototherapy (described above) according to age, clinical condition, location and extension of the dermatosis. In order to execute the treatment safely, all patients were subjected to the following laboratory exams, according to the type of phototherapy: hemogram, hepatic transaminases, creatinine, urea, ANF, pregnancy test for the women and ophthalmologic examination (fundoscopy). ${ }^{11}$

The lesions were assessed before and after treatment by clinical palpation, performed by the author herself, looking for resistance to pinching or skin hardening. This cutaneous folding was judged in a scale rating from zero (no sclerosis, normal folding), to three (severe sclerosis, no folding) as described by Rook et al, in $1992 .{ }^{12}$

The group underwent ultrasound examination of the skin, aiming at measuring the dermis thickness before the treatment and at the end of the $12^{\text {th }}$ week of phototherapy. Whenever possible both the area compromised by the disease and the contra lateral area of normal skin were assessed. The device used in the study was the high frequency ultrasound Toshiba Aplio XG with multifrequency transdutor multifrequencial from 7 to $14 \mathrm{MHz}$ for better defining the skin structures.

\section{RESULTS}

With an average of 10 sessions of phototherapy the lesions started to have some clinical improvement. The clinical palpation showed softening of all the studied lesions, both the inflammatory and the 
TABLE 1: Assessment of the clinical response obtained by skin palpation of the inflammatory lesions of localized scleroderma treated with phototherapy

\begin{tabular}{clllll}
\hline Patient & Type of Scleroderma & Lesion & Place & Pre-treatment (1) & Post-treatment (2) \\
\hline 1 & Morphea & 1 & Left thigh & 3 & 2 \\
2 & Morphea & 2 & Left infrascapular region & 3 & 1 \\
3 & Generalized & 3 & Dorsum, left & 3 & 1 \\
& & 4 & Dorsum, right & 3 & 2 \\
& & 5 & Right calf & 3 & 2 \\
4 & Morphea & 6 & Left calf & 2 & 1 \\
5 & Morphea & 7 & Right hypochondrium & 3 & 0 \\
\hline
\end{tabular}

Dermatology Clinic - Departament of Medicine of the Santa Casa de São Paulo, January to December de 2007.

(1) Total score $=23$

(2) Total score $=11$

stable ones, with a reduction of the scores when pre and post treatments were compared. On table 1 it can be seen that the sum of the pre-treatment scores was 23 points. The sum of post treatment scores was 11 points. As such, the difference between the initial and final values was 12 points, indicating a decrease of $52 \%$ of the punctuation in terms of analysis of clinical improvement. On table 2 it can be observed that all the lesions had a decrease of the scores post treatment. The sum of the pre-treatment scores was 27 points and the sum of the scores post treatment was 14 points. When both scores are compared the difference was 13 points, showing that there was a reduction of $48 \%$ of the punctuation when assessing the clinical improvement.

At ultrasound examination most lesions assessed had a decrease of the dermal thickness and only some retained its original measure (Tables 3 and 4). The result of the ultrasound on the contra lateral side was considered as the normal dermal thickness for each patient. This data was used to assess the results with the ultrasound after the treatment, comparing with the value of the initial exam (Figures 1, 2, 3 and 4). In some patients with extensive lesions two to four measures were obtained on the same lesion. On patient number three, with the generalized form, it was not possible to do the contra lateral ultrasound as there was no normal skin. The average values of dermal thickness at this location, based on the personal experience of the radiologist, were considered.

There was no difference in relation to treatment response in terms of the type of phototherapy used.

The lesions studied on the inflammatory stage had, at the initial ultrasound, higher dermal thickness than normal skin (Table 3). There was a decrease of the thickness of all lesions with the treatment, except from lesion number six of patient number three, which remained unaltered. On the second last column of the table there is the value of the decrease

TABLE 2: Assessment of the clinical response obtained by skin palpation of the stable lesions of localized scleroderma treated with phototherapy

\begin{tabular}{clllll}
\hline Patient & Type of Scleroderma & Lesion & Place & Pre-treatment (1) & Post-treatment (2) \\
\hline 6 & Morphea & 9 & Right forearm & 3 & 1 \\
& & 10 & Right arm & 3 & 1 \\
7 & Linear & 11 & Left upper limb & 3 & 2 \\
8 & Linear & 12 & Right lower limb & 3 & 2 \\
& & 13 & Right buttock & 3 & 2 \\
9 & Morphea & 14 & Right thigh & 3 & 2 \\
10 & Linear & 15 & Right leg & 3 & 1 \\
11 & Linear & 16 & Frontal area & 3 & 2 \\
\hline
\end{tabular}

Clínica de Dermatologia - Departamento de Medicina da Santa Casa de São Paulo, janeiro a dezembro de 2007.

(1) Escore total $=27$

(2) Escore total $=14$ 
TABLE 3: Type of phototherapy used and assessment of the response by skin ultrasound (in millimeters) of the inflammatory lesions of localized scleroderma treated with phototherapy

\begin{tabular}{|c|c|c|c|c|c|c|c|c|c|}
\hline Patient & $\begin{array}{l}\text { Type of } \\
\text { scleroderma }\end{array}$ & $\begin{array}{l}\text { Type of pho- } \\
\text { totherapy }\end{array}$ & Lesion & Place & $\begin{array}{l}\text { US pre } \\
\text { (mm) }\end{array}$ & $\begin{array}{l}\text { US post } \\
\text { (mm) }\end{array}$ & $\begin{array}{l}\text { USG }\left({ }^{1}\right) \text { con- } \\
\text { tralate }(\mathrm{mm})\end{array}$ & $\begin{array}{l}\text { Decrease } \\
\text { in } \mathbf{m m}\left({ }^{2}\right)\end{array}$ & $\begin{array}{l}\text { \% of im- } \\
\text { provement }\end{array}$ \\
\hline \multirow[t]{2}{*}{1} & Morphea & PUVA & 1 & Proximal thigh & 3,7 & 2,1 & 1,6 & 1,6 & 76 \\
\hline & & & & Distal thigh & 3,4 & 2,6 & 1,6 & 0,8 & 44 \\
\hline \multirow[t]{2}{*}{2} & Morphea & Topical PUVA & 2 & $\begin{array}{l}\text { Border of the } \\
\text { lesion }\end{array}$ & 1,7 & 1,3 & 1,3 & 0,4 & 100 \\
\hline & & & & $\begin{array}{l}\text { Center of the } \\
\text { lesion }\end{array}$ & 2,6 & 2,3 & 1,4 & 0,3 & 25 \\
\hline \multirow[t]{4}{*}{3} & Generalized & $\begin{array}{l}\text { Narrow } \\
\text { band UVB }\end{array}$ & 3 & Dorsum, left & 5,5 & 4,0 & \# (3) & 1,5 & 60 \\
\hline & & & 4 & Dorsum, right & 4,5 & 4,2 & \# (3) & 0,3 & 20 \\
\hline & & & 5 & Right calf & 2,8 & 2,1 & $\#(1,5)$ & 0,7 & 54 \\
\hline & & & 6 & Left calf & 2,3 & 2,3 & $\#(1,5)$ & - & 0 \\
\hline \multirow[t]{2}{*}{4} & Morphea & Topical PUVA & 7 & $\begin{array}{l}\text { Border of the } \\
\text { lesion }\end{array}$ & 1,5 & 1,4 & 1,0 & 0,1 & 20 \\
\hline & & & & $\begin{array}{l}\text { Center of the } \\
\text { lesion }\end{array}$ & 1,2 & 1,0 & 1,0 & 0,2 & 100 \\
\hline 5 & Morphea & Topical PUVA & 8 & Cervical, left & 1,8 & 1,4 & 1,4 & 0,4 & 100 \\
\hline
\end{tabular}

Dermatology Clinic - Departament of Medicine of the Santa Casa de São Paulo, January to December de 2007.

(1) Normal skin

(2) Millimeters

of the thickness in millimetres of each treated lesion, and on the last column the percentage of the decrease of the dermal thickness in each lesion. On table 4 (lesions on stable stage) it is observed that the values of the contra lateral ultrasound, considered as normal skin, had highest measures than the studied lesions. All lesions had lower thickness than normal skin before treatment, confirming the stable stage of the disease. The post treatment ultrasound showed that in four measures (patients seven, eight and nine) there was no alteration, retaining the thickness of the initial exam. However, there was decrease of dermal thickness in at least one measure of each patient, when comparing ultrasounds pre and post treatment (last column of table 4 ).

No acute side effect like itch, erythema or burns was observed.

TABLE 4: Type of phototherapy used and assessment of the response by skin ultrasound (in millimeters) of the stable lesions of localized scleroderma treated with phototherapy

\begin{tabular}{|c|c|c|c|c|c|c|c|c|}
\hline Patient & $\begin{array}{l}\text { Type of } \\
\text { scleroderma }\end{array}$ & $\begin{array}{l}\text { Type of } \\
\text { phototherapy }\end{array}$ & Lesion & Place & $\begin{array}{l}\text { US pre } \\
\text { (mm) }\end{array}$ & $\begin{array}{l}\text { US post } \\
(\mathrm{mm})\end{array}$ & $\begin{array}{l}\mathrm{US}^{(1)} \text { con- } \\
\text { tralate }(\mathrm{mm})\end{array}$ & $\begin{array}{l}\text { Decrease } \\
\text { in } \mathbf{m m}^{(2)}\end{array}$ \\
\hline \multirow[t]{2}{*}{6} & Morphea & Topical PUVA & 9 & Forearm & 1,3 & 0,6 & 1,4 & 0,7 \\
\hline & & & 10 & Arm & 1,0 & 0,8 & 1,4 & 0,2 \\
\hline \multirow[t]{2}{*}{7} & Linear & Narrow band & 11 & Wrist & 1,0 & 0,9 & 1,6 & 0,1 \\
\hline & & UVB & & Forearm & 0,7 & 0,7 & 1,0 & - \\
\hline \multirow[t]{3}{*}{8} & Linear & Narrow band & 12 & Proximal thigh & 1,2 & 1,2 & 1,3 & - \\
\hline & & UVB & & Distal thigh & 1,0 & 0,9 & 1,2 & 0,1 \\
\hline & & & 13 & Buttock & 1,0 & 1,0 & 1,2 & - \\
\hline \multirow[t]{2}{*}{9} & Morphea & PUVA & 14 & Thigh & 1,6 & 1,6 & 2,2 & - \\
\hline & & & 15 & Leg & 1,2 & 1,1 & 1,9 & 0,1 \\
\hline 10 & Linear & Topical PUVA & 16 & Frontal area & 0,8 & 0,6 & 1,3 & 0,2 \\
\hline 11 & Linear & $\begin{array}{l}\text { Narrow band } \\
\text { UVB }\end{array}$ & 17 & Forearm & 1,2 & 1,1 & 1,5 & 0,1 \\
\hline
\end{tabular}

Dermatology Clinic - Departament of Medicine of the Santa Casa de São Paulo, January to December de 2007.

(1) Normal skin

(2) Millimeters 


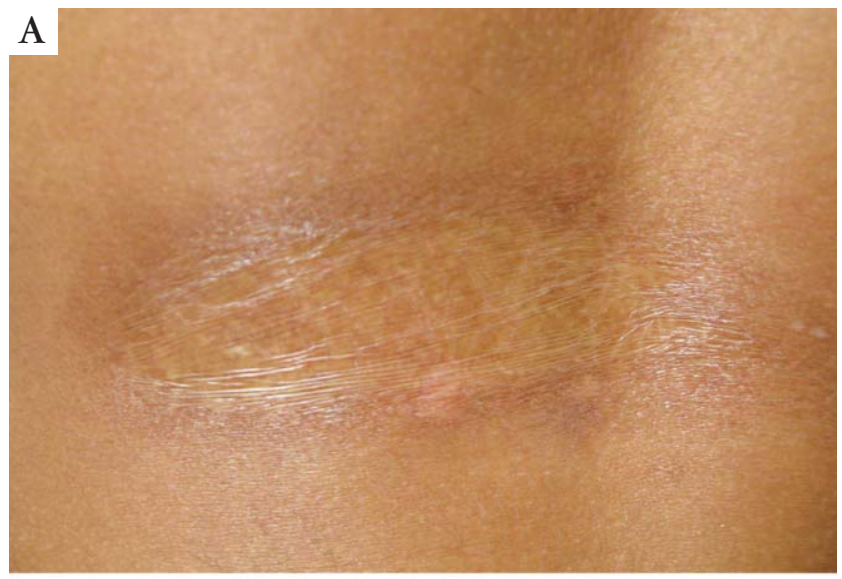

B

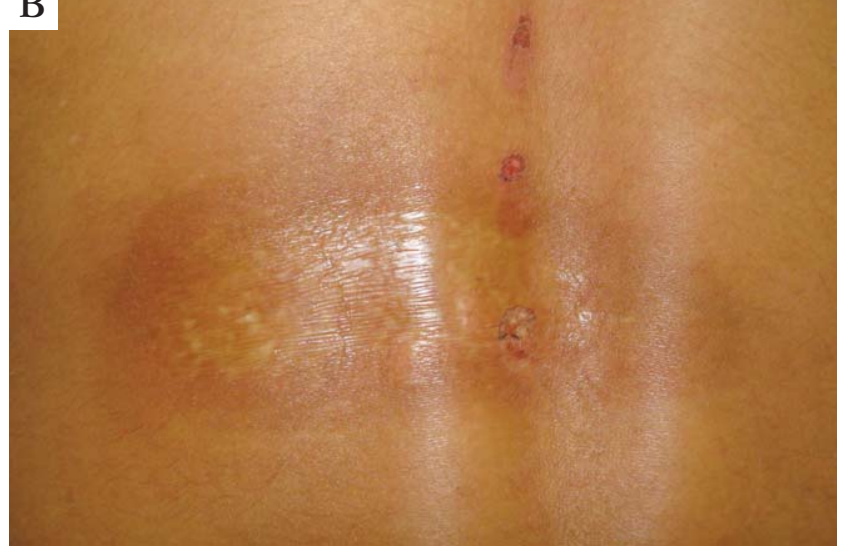

FIGURE 1: Morphea scleroderma - inflammatory stage (patient number 2). Pre-treatment with phototherapy; B. Morphea scleroderma - inflammatory stage (patient number

2). Post-treatment with phototherapy

\section{DISCUSSION}

Phototherapy contributes to the improvement of scleroderma through three main actions, which are: immunomodulation of inflammation, stimulus to collagen synthesis and $\mathrm{T}$ lymphocytes apoptosis. ${ }^{13-17}$

The results of the clinical and ultrasound evaluation after treatment with phototherapy showed improvement of the localized sclerodema lesions in all patients. The clinical palpation showed softening of the lesions. The ultrasound contributed to complement this assessment.

In terms of clinical assessment, tables 1 and 2 show a reduction of the scores of $52 \%$ and $48 \%$ respectively, an indication that both the inflammatory and the stable lesions responded to treatment with phototherapy. This result demonstrates that even in more advanced lesions, with sclerosis and atrophy already installed, the treatment contributed by softening the skin.

When analysing the types of lesions, different responses in relation to the type of phototherapy employed could not be not seen. The restrict number of lesions studied, in both groups, did not allow an
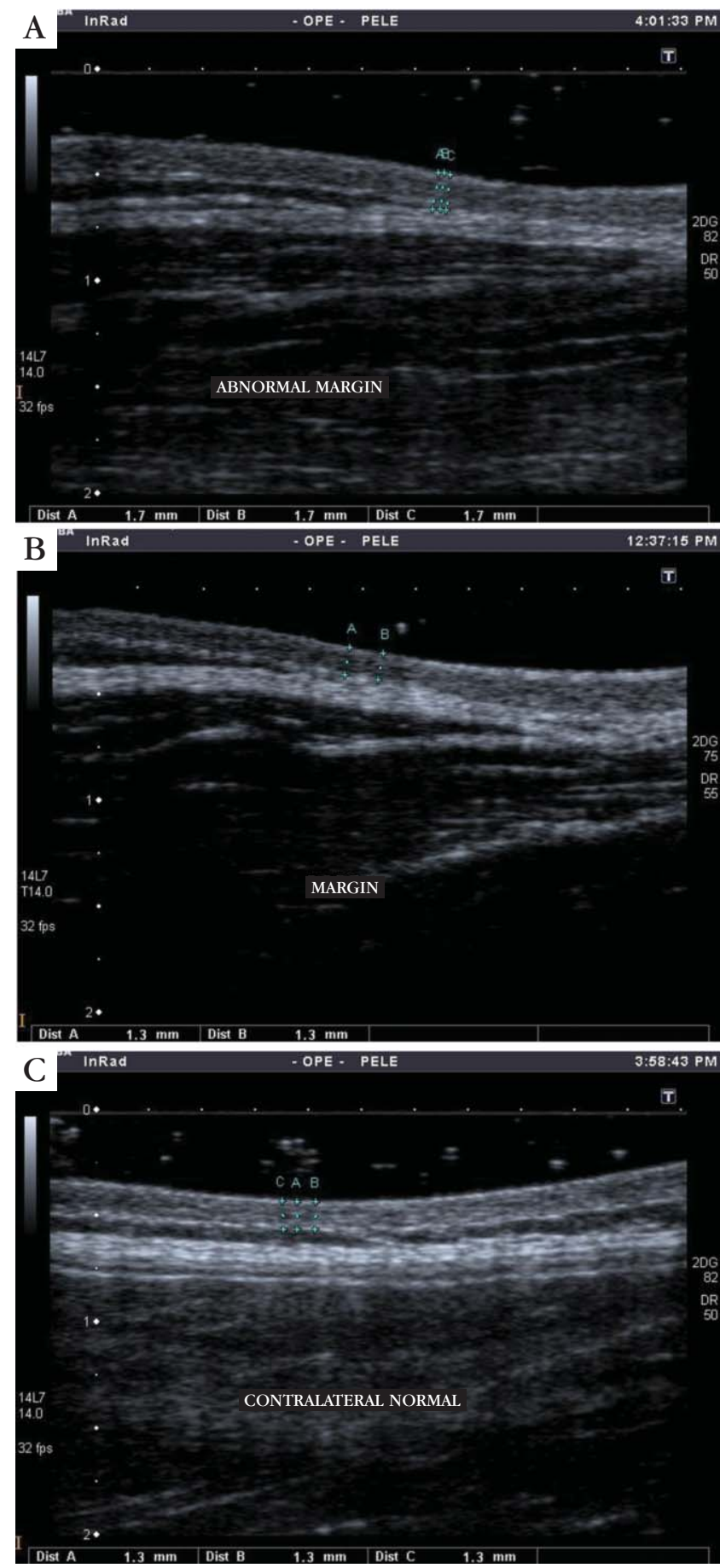

Figure 2: A. Morphea scleroderma - inflammatory stage (patient number 2). Pre-treatment. High frequency ultrasound Dermis: 1, 7 millimeters; B. Morphea scleroderma - inflammatory stage (patient number 2). Post-treatment. High frequency ultrasound- Dermis: 1, 3 millimeters; C. Morphea scleroderma inflammatory stage (patient number 2). Contralateral. High frequency ultrasound - Dermis: 1,3 millimeters

evaluation of the type of phototherapy indicated. Literature studies show that phototherapy using systemic or topical PUVA or narrow band UVB were effective in the treatment of localized scleroderma. ${ }^{2,5,8,9}$ The 

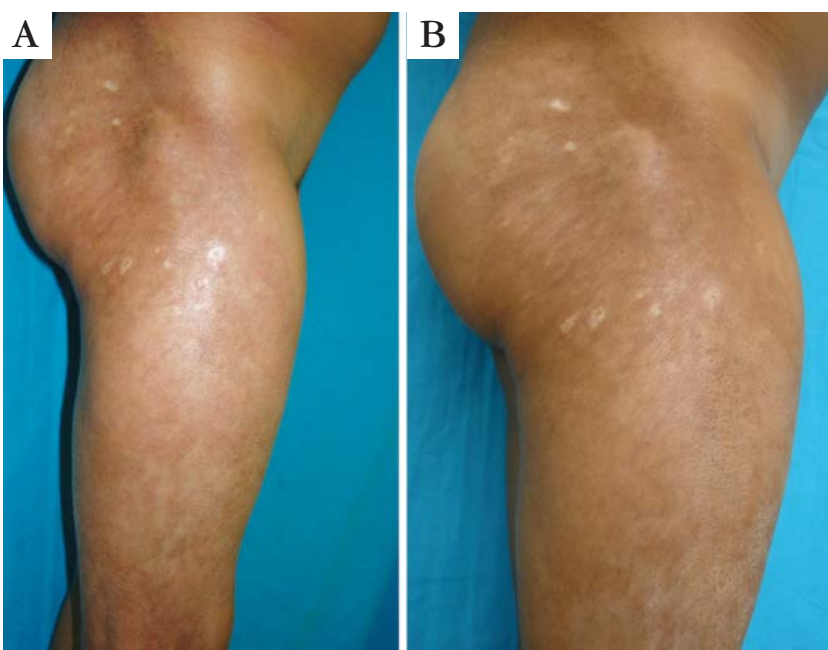

Figure 3: A. Linear scleroderma- stable stage (patient number 8 / lesion 12). Pre-treatment with phototherapy; B. Linear scleroderma- stable stage (patient number 8 / lesion 12). Post-treatment with phototherapy

proper indication of each type of phototherapy might also have contributed to the good clinical response showed by the patients.

The results from the ultrasound examination were divided in two groups according to the classification of the evolutive stage of the lesions (Table 3 and 4). On table 3 it was observed that, in all inflammatory lesions, the contra lateral side (considered normal) had a dermal thickness lower that the involved site. After treatment all lesions were less thick, varying from 20 to $100 \%$. Only one patient (number three) had one lesion, among the four studied, with no change in millimetres at the ultrasound examination. This case demonstrates that phototherapy can have different responses even on the same patient. It is interesting to note that the clinical assessment of this lesion had an initial score of three points and, after treatment; the final score was two points, indicating skin softening. This patient number three, with generalized cutaneous scleroderma in the inflammatory stage, was sent by the endocrinology outpatients' clinic because she could no longer inject the subcutaneous insulin due to the skin hardening. After five weeks of phototherapy the skin started to soften and it was necessary to reduce the dose of insulin as the cutaneous absorption of the drug increased. Maybe a longer treatment is needed so that the generalized, more severe forms, respond to phototherapy in a more uniform way. On table 4 , the stable lesions had lower thickness that the contra lateral measures, considered normal. With the treatment there was an even more pronounced decrease of the dermal thickness in seven measures, and in four the measures remained unaltered when assessed by the ultrasound. However, all lesions had a clinical improvement, as observed by the
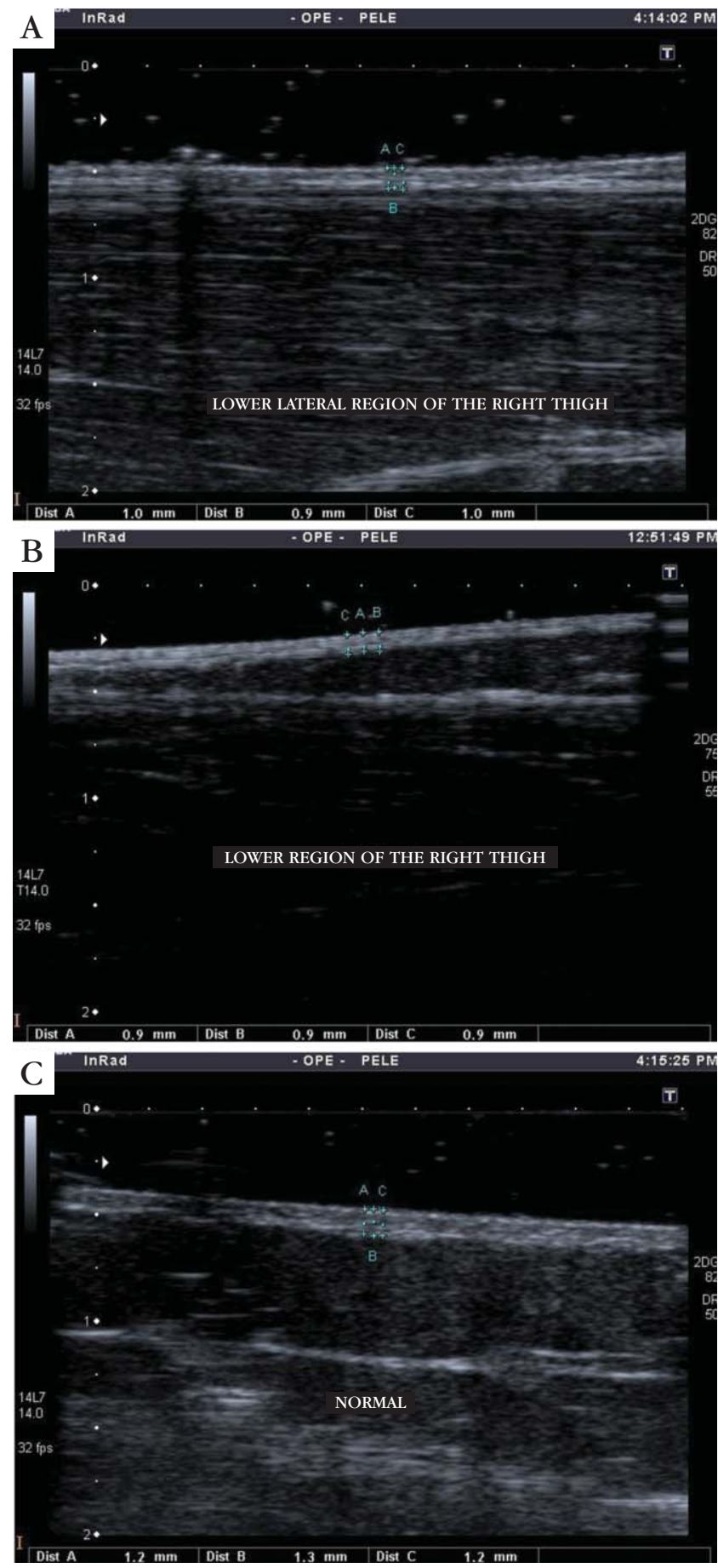

Figure 4: A. Linear scleroderma- stable stage (patient number 8 / lesion 12). Pre-treatment. High frequency ultrasound - dermis: 1, 0 millimeters; B. Linear scleroderma- stable stage (patient number 8 / lesion 12). Post-treatment. High frequency ultrasound - dermis: 0,9 millimeters; C. Linear scleroderma- stable stage (patient number 8 / lesion 12). Contralateral. High frequency ultrasound - dermis: 1,2 millimeters

lowering of the scores. In this group (stable lesions) the score dropped $48 \%$. We cannot state that the phototherapy was not effective on the stable lesions. The decrease of the thickness of the lesions with photothe- 
rapy is probably explained by its own mechanism of action in scleroderma. As already reported, the synthesis and activity of collagenase is stimulated by phototherapy. ${ }^{17}$ The increment of this enzyme might have contributed to the occurrence of the existing collagen degradation with subsequent remodelling. It was clearly demonstrated that the results obtained by the skin ultrasound depend on the evolutive stage of the localized scleroderma lesions.

The inclusion of a control group on the methodology would give even more value to the results obtained.

\section{CONCLUSIONS}

The proposed treatment was effective in all lesions, regardless of the type of phototherapy used. Improvement was observed in all treated lesions and confirmed by clinical assessment and ultrasound examination of the skin.

Our results encourage us to continue our work, including a control group, improving the scientific methodology more and more.

\section{REFERENCES}

1. Sampaio SAP, Rivitti EA. Dermatologia. 3 ed. rev. e ampl. São Paulo: Artes Médicas; 2007. Capítulo 32, Afeccõoses do conectivo: p.476-82.

2. Duarte AA. Colagenoses e a dermatologia. São Paulo: Ed.do Autor; 2004. Capítulo 6, Esclerodermia: p.88-105.

3. Falanga V, Killoran CE. Morphea. In: Wolff K, Goldsmith LA, Katz SI, Gilchrest BA, Paller AS, Leffell DJ, editors. Fitzpatrick 's Dermatology in general medicine. 7th ed. New York: McGraw-Hill; 2008. p.543-6.

4. Bono W, Dupin N. Localized scleroderma (morphea). Presse Med. 2006;35:1923-8.

5. Röcken M, Ghoreschi K. Morphea and lichen sclerosus. In: Bolognia JL, Jorizzo JL, Rapini RP, Callen JP, Horn TD, Mancini AJ, et al. Dermatology. Philadelphia: Elsevier Limited; 2008. p.1469-83.

6. Salmon-Her V, Eschard C, Kalis B. Morphées: Classification et prise em charge. Ann Dermatol Venereol. 1998;125:283-90

7. Sehgal VN, Srivastava G, Aggarwal AK, Behl PN, Choudhary M, Bajad P. Localized scleroderma/morphea. Int J Dermatol. 2002;41:467-75.

8. Brenner M, Herzinger T, Berking C, Plewig G, Degitz K. Phototherapy and photochemotherapy of sclerosing skin diseases. Photodermatol Photoimmunol Photomed. 2005;21:157-65.

9. Kreuter A, Hyun J, Stucker M, Sommer A, Altmeyer P, Gambichler T. A randomized controlled study of low-dose UVA1, medium-dose, and narrowband UVB phototherpy in the treatment of localized scleroderma. J Am Acad Dermatol. 2006;54:440-7.

10. Schwarz T, Halliday GM. Photoimmunology. In: Lim HW, Honigsmann H, Hawk JLM. Photodermatology. New York: Informa Healthcare USA; 2007. p.55-74.

11. Duarte I, Buense R, Kobata C. Fototerapia. An Bras Dermatol. 2006;81:74-82.

12. Rook AH, Freundlich B, Jegasothy BV, Perez MI, Barr WG, Jimenez SA, et al. Treatment of systemic sclerosis with extracorporeal photochemoterapy. Arch Dermatol. 1992;128:337-46.

13. Breuckmann F, Gambichler T, Altmeyer P, Kreuter A. UVA/UVA1 phototherapy and PUVA photochemotherapy in connective tissue diseases and disorders: a research based review. BMC Dermatology. 2004;4:11.

14. Weichenthal M, Schwarz T. Phtotherapy: How does UV work? Photodermatol Photoimmunol Photomed. 2005;21:260-6.

15. Kerscher M, Meurer M, Sander C, Volkenandt M, Lehmann P, Plewig G, et al. PUVA bath photochemotherapy for localized scleroderma. Evaluation of 17 consecutive patients. Arch Dermatol. 1996;132:1280-2.

16. Stege H, Berneburg M, Humke S, Klammer M, Grewe M, Grether-Beck S, et al. Highdose UVA1 radiation therapy for localized scleroderma. J Am Acad Dermatol. 1997;36:938-44.

17. Gruss C, Reed JA, Altmeyer P, McNutt NS, Kerscher M. Induction of interstitial collagenase (MMP-1) by UVA1 phototherapy in morphea fibroblasts. Lancet. 1997;350:1295-6.

\footnotetext{
MAILING ADDRESS / ENDEREÇO PARA CORRESPONDÊNCIA : Roberta Buense Bedrikow

Rua Monte Alegre, 523, conj. 92, Perdizes

05014-000 São Paulo, SP, Brazil

Phone: +55 (11) 3868-4947 (comercial/fax)

E-mail:buense@fototerapia.com.br
}

How to cite this article/Como citar este artigo: Buense R, Duarte IAG, Bouer M. Localized scleroderma: assessment of the therapeutic response to phototherapy. An Bras Dermatol. 2012;87(1):63-9. 